\title{
Rekayasa Praktek Pendidikan Karakter Sebagai Strategi Pembelajaran Sosiologi Berorientasi Hots
}

$\underline{\text { Afiri N Kurniawan }^{\mathbf{a}}}$

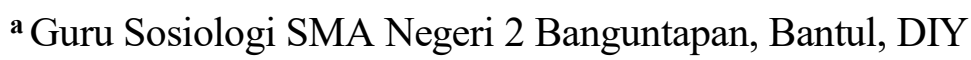

\begin{tabular}{ll}
\hline Informasi artikel & ABSTRAK \\
\hline Kata Kunci: & Kegagalan pendidikan karakter dapat berdampak signifikan pada praktek \\
pendidikan karakter, mata & dan sudah saatnya bagi para peneliti pendidikan karakter untuk \\
pelajaran sosiologi & mempelajari beberapa alasan mengapa penelitian - praktek tampaknya \\
& berjauhan dalam bidang pendidikan karakter. Sosiologi dapat digunakan \\
& untuk membahas bagaimana rekayasa praktek pendidikan karakter \\
& digunakan. Melalui cara ini, maka pendidikan karakter yang dapat \\
& dikembangkan pada jenjang Sekolah Menengah Atas (SMA) tidak hanya \\
& selalu berkaitan/berfokus pada etika (karakter moral), namun juga \\
& memperhatikan keunggulan (karakter kinerja) yang muncul dalam \\
kurikulum sosiologi SMA. & \\
\hline Keywords: & ABSTRACT \\
character education, & Character education failure can have a significant impact on practice \\
sociology subjects & and it is time for character education researchers to study several \\
& reasons why research seems to be far apart in the field of character \\
& education. Sociology can be used to discuss how the engineering \\
practice of character education is used. Through this method, character & education that can be developed at the level of high school (SMA) is not \\
only always related / focused on ethics (moral character), but also \\
attention to excellence (character performance) that appears in high \\
school sociology curricula.
\end{tabular}

\section{PENDAHULUAN}

Untuk mempersiapkan kaum muda menjalani kehidupan yang berkembang, dibutuhkan visi yang lebih luas tentang pendidikan karakter, bukan visi yang selama ini memandunya. Sampai saat ini, pengembangan pendidikan karakter di Sekolah Menengah Atas (SMA) lebih berfokus pada etika (karakter moral) dan kurang memperhatikan keunggulan (karakter kinerja), baik dalam intrakurikuler
(Kristiawan, 2017; Dianti, 2014; Sadia, Arnyana, \& Muderawan, 2013), maupun ekstrakurikuler (Yanti, Adawiah, \& Matnuh, 2016). Konsepsi pendidikan karakter di jenjang sekolah menengah (atas) perlu diperluas agar kaum muda dapat mempersiapkan dan menentukan masa depannya $(3 \mathrm{C}=$ Career, Colege, and Civic-Life) dengan tepat. Sementara itu, kajian tentang upaya pengajaran pendidikan karakter belum banyak dilakukan di jenjang Sekolah Menengah 
Atas (SMA), meskipun tantangan yang terbesar berhubungan dengan karakter justru berada di tingkat SMA (Davidson, Lickona, \& Khmelkov, 2015).

Jika masalah seperti buruknya prestasi, putus sekolah, kecurangan akademik, tawuran, kekerasan, narkoba, dan aktivitas seksual paling menonjol ditemukan pada jenjang SMA, maka sudah seharusnya SMA menganut pendidikan karakter sebagai salah satu strategi utama dalam upaya perbaikan sekolah. Para pendidik karakter berpendapat bahwa dengan membantu menciptakan lingkungan sekolah yang aman, peduli, dan tertib, pendidikan karakter menciptakan kondisi yang kondusif untuk mengajar dan belajar dan secara tidak langsung mendorong prestasi akademik (Lickona, 2004; Schwartz, Beatty, \& Daćhnowicz, 2006). Misalnya, Lickona \& Davidson (2005) melakukan studi selama dua tahun mengenai pendidikan karakter SMA, yang berfokus pada upaya membantu semua kaum muda memaksimalkan potensi mereka untuk memenuhi kehidupan yang bermakna melalui proyek „Smart \& Good High Schools". Konsepsi pokok dari Smart \& Good High Schools adalah tentang karakter manusia yang memiliki dua bagian utama: performance character (karakter kinerja) dan moral character (karakter moral). Untuk mewujudkan Smart \& Good High Schools, diperlukan pergeseran paradigma (mindset) dalam berpikir tentang karakter dan pendidikan karakter.

Karakter bukan hanya tentang "melakukan hal yang benar" dalam makna etis (moral) melainkan juga tentang melakukan pekerjaan sebaik mungkin yang dapat dideskripsikan melalui konsep karakter kinerja (Davidson, Lickona, \& Khmelkov, 2015). Jika demikian, maka pendidikan karakter tidak hanya membantu peserta didik agar dapat bergaul, melainkan juga tentang mengajar mereka untuk bekerja keras, mengembangkan bakat mereka, dan bercita-cita mencapai keunggulan dalam setiap usaha.

Lebih khusus, Strike (2015) menyarankan bahwa pendidikan karakter dapat diajarkan melalui materi pelajaran, karena: (1) materi pelajaran adalah salah satu sumber potensial norma, dan (2) menguasai materi pelajaran merupakan cara baru untuk melihat dunia, merasakannya dengan cara yang berbeda, dan, bahkan, mengubahnya dengan cara tertentu. Namun, untuk mengintegrasikan pendidikan karakter dalam pengajaran disiplin ilmu (mata pelajaran) tidaklah mudah. Leming (2006) mengemukakan satu fakta sebagai alasannya bahwa guru 
SMA cenderung mengidentifikasikan diri mereka sebagai spesialis bidang pelajaran dan memberikan sedikit penekanan pada pengembangan karakter dibandingkan guru SD dan SMP. Guru SMA biasanya tidak melihat pendidikan karakter berkontribusi langsung terhadap pembelajaran akademik karena mereka cenderung menyamakan pendidikan karakter dengan"diskusi etika" atau dengan kegiatan sosial dan emosi yang "menyentuh rasa" yang mereka pandang tidak begitu penting bagi tuntutan kurikulum akademik. Dalam konteks ini, maka diperlukan strategi pengajaran khusus sesuai dengan karakteristik mata pelajaran.

Telah banyak strategi untuk mengajarkan pendidikan karakter di sekolah yang dikemukakan para ahli berbasis pada riset. Namun, Leming (2015) mengingatkan bahwa kegagalan penelitian pendidikan karakter dapat berdampak signifikan pada praktek dan sudah saatnya bagi para peneliti pendidikan karakter untuk mempelajari beberapa alasan mengapa penelitian praktek tampaknya berjauhan dalam bidang pendidikan karakter. Sejumlah faktor penting yang dapat mempengaruhi antara lain: (1) manajemen sekolah sering skeptis terhadap hasil penelitian dan menemukan studi penelitian sangat tidak jelas atau tidak meyakinkan mengenai implikasinya bagi praktek, (2) temuan penelitian seringkali terlepas dari, dan tidak dilihat berhubungan dengan praktek, (3) hasil penelitian sering mengabaikan konteks di mana pemahaman guru ada dan berkembang, sehingga penelitian sering tidak mempunyai daya tarik bagi guru dan sekolah, dan (4) konteks sosial ekonomi, dan politik sekolah, serta strategi pemasaran pengembang kurikulum seringkali mempengaruhi penelitian dalam memperoleh akses ke ruang kelas.

Cara yang lebih bermanfaat untuk mengatasi kesenjangan antara penelitian dan praktek bukanlah dengan fokus hanya pada penelitian yang lebih banyak dan lebih baik, tetapi dengan membawa proses pengetahuan dan bukti yang dihasilkan ke tingkat praktis. Untuk tujuan ini, Burkhart \& Schoenfield (2003) menyarankan bahwa pengetahuan yang dihasilkan melalui proses rekayasa adalah model yang lebih baik untuk meningkatkan praktek pendidikan daripada model penelitian ilmiah. Pendekatan seperti itu tidak akan terlalu fokus pada pengembangan pandangan yang dapat menggeneralisir bagaimana sekolah dan pedagogi berjalan, dan sebaliknya akan lebih langsung terlibat dalam pengembangan solusi berkualitas 
tinggi pada masalah-masalah praktis. Mengadopsi pemikiran Burkhart \& Schoenfield, Leming (2015) menjelaskan bahwa mengembangkan karakter pada remaja dapat dibandingkan dengan tugas seorang insinyur membangun jembatan, yang membutuhkan kreativitas dalam mendesain program pendidikan karakter karena senantiasa dipengaruhi oleh pengetahuan lokal, budaya sekolah, kurikulum sekolah, dan nilai-nilai politik dan moral komunitas setempat.

Berdasarkan paparan di atas, maka dirasa perlu untuk mengelobarasi dan merumuskan gagasan tentang rekayasa praktik pendidikan karakter bagi siswa SMA yang berbasis pada disiplin ilmu (mata pelajaran). Secara khusus, artikel ini berupaya menawarkan konsepsi tentang rekayasa praktek pendidikan karakter sebagai strategi pengajaran Sosiologi di SMA. Fokus penguatan pendidikan karakter adalah performance character (karakter kinerja) yang sesuai dengan karakteristik Sosiologi sebagai disiplin ilmu (mata pelajaran) yang diajarkan di SMA. Selain berfokus pada pendidikan karakter, desain strategi pembelajaran sosiologi yang akan dipaparkan berorientasi HOTS (Higher Order Thinking Skills) atau keterampilan berpikir tingkat tinggi sesuai dengan Kurikulum 2013 yang saat ini berlaku. Secara keseluruhan, hal itu dimaksudkan untuk menumbuhkan kesadaran individual atau diri dan sosial siswa di tengah keragaman sosial atau pluralitas yang ada, menghormati perbedaan dan bersikap toleran terhadap perbedaan di tengah pluralitas masyarakat Indonesia. Agar gagasan mengenai rekayasa praktek pendidikan karakter ini lebih implementatif, maka paparan dalam artikel ini juga akan dilengkapi beberapa contoh desain pembelajaran sosiologi berorientasi HOTS melalui rekayasa praktek pendidikan karakter kinerja (performance character).

\section{PEMBAHASAN}

Secara mikro, pengembangan karakter dibagi dalam empat pilar, yakni kegiatan belajar-mengajar di kelas, kegiatan keseharian dalam bentuk pengembangan budaya satuan pendidikan formal dan nonformal, kegiatan kokurikuler dan/atau ekstrakurikuler, serta kegiatan keseharian di rumah dan masyarakat (Kemdiknas, 2010). Dalam kegiatan belajar-mengajar di kelas, pengembangan karakter dilaksanakan dengan menggunakan pendekatan terintegrasi dalam semua materi pembelajaran (Kurniawan, 2013; Suyadi,2015). Pendidikan karakter untuk 
mata pelajaran sosial dapat dipadukan antara keterampilan berpikir dengan keterampilan sosial (Fogarty, 1991). Artikel ini secara khusus akan membahas bagaimana rekayasa praktek pendidikan karakter digunakan sebagai salah satu strategi pembelajaran sosiologi berorientasi HOTS (Higher Order Thinking Skills). Pembahasan terdiri dari dua bagian, yaitu: (1) identifikasi Kompetensi Dasar (KD) Sosiologi yang berkaitan dengan HOTS dan nilai-nilai karakter, dan (2) implementasi rekayasa praktek pendidikan karakter dan pembelajaran sosiologi berorientasi HOTS.

\section{Identifikasi Kompetensi Dasar: Pembelajaran HOTS dan Nilai-nilai Karakter}

Pengintegrasian pendidikan karakter ke dalam semua materi pembelajaran dilakukan dalam rangka mengembangkan kegiatan intervensi atau rekayasa. Sinergi antara pendidikan karakter dengan materi pembelajaran dirancang, dikembangkan, dan dilaksanakan untuk saling melengkapi. Dalam pengembangan pendidikan karakter, materi pembelajaran dipahami sebagai integrasi pesan dan alat, yaitu sebagai wahana pembudayaan dan pemberdayaan individu. Misalnya, Pendidik Sosiologi harus sadar bahwa pembahasan materi sosiologi diarahkan untuk mengembangkan kemampuan peserta didik agar: (1) memiliki kesadaran individual dan sosial yang tinggi, (2) memiliki kepekaan dan kepedulian terhadap masalah- masalah sosial dan tanggung jawab pemecahan masalah sosial, dan (3) memiliki keberdayaan diri dan kemampuan melakukan pemberdayaan (Kemdikbud, 2017). Selain itu, tujuan pembelajaran Sosiologi diarahkan untuk menumbuhkan kualitas berpikir yang mampu mendorong keterlibatan siswa dalam dunia publik. Dengan kata lain, pembelajaran Sosiologi mementingkan penguasaan pengetahuan, nilai kemanusiaan dan keterlibatan sosial.

Secara eksplisit dapat dipahami bahwa tujuan pembelajaran sosiologi di SMA berkaitan erat dengan: (1) bagaimana memampukan siswa agar terlatih untuk menggunakan keterampilan berpikir tingkat tinggi (HOTS), dan (2) bagaimana menanamkan nilai-nilai pendidikan karakter kinerja (performance character) dalam proses pembelajaran sosiologi. Dengan mencermati struktur kurikulum sosiologi SMA (Kemdikbud, 2017) dan selanjutnya menggunakan taksonomi tujuan pembelajaran berorientasi HOTS (Anderson \& Krathwohl, 2001) serta mengadopsi Delapan Kekuatan Karakter (Eight 
Strengths of Character) (Lickona \& Davidson,2005), maka diperoleh hasil identifikasi materi sosiologi sebagai berikut: 
Tabel 2.

Hasil Identifikasi Kompetensi Dasar Sosiologi

\begin{tabular}{|c|c|c|c|}
\hline \multirow{2}{*}{ Kelas } & \multirow{2}{*}{$\begin{array}{l}\text { Kompetensi Dasar } \\
\text { (KD) }\end{array}$} & \multicolumn{2}{|r|}{ Materi } \\
\hline & & HOTS & Nilai Karakter \\
\hline \multirow[t]{2}{*}{$\mathrm{X}$} & $\begin{array}{l}\text { 3.2 Mengenali dan mengidentifikasi realitas individu, } \\
\text { kelompok }\end{array}$ & \multirow{2}{*}{\multicolumn{2}{|c|}{$\begin{array}{l}\text { - Mandiri } \\
\text { - Kemampuan beradaptasi }\end{array}$}} \\
\hline & $\begin{array}{l}\text { 4.2 Mengolah realitas individu, kelompok, dan hubungan } \\
\text { sosial } \\
\text { sehingga mandiri dalam memposisikan diri dalam }\end{array}$ & & \\
\hline \multirow[t]{8}{*}{$\mathrm{XI}$} & $\begin{array}{l}\text { 3.2 Menganalisis permasalahan sosial dalam kaitannya } \\
\text { dengan } \\
\text { pengelompokan sosial dan kecenderungan eksklusi }\end{array}$ & \multirow[t]{2}{*}{$\mathrm{C} 4$} & \multirow[t]{2}{*}{$\begin{array}{l}\text { - Kepedulian sosial } \\
\text { - Berpikir kritis }\end{array}$} \\
\hline & $\begin{array}{l}\text { 4.2 Memberikan respons dalam mengatasi } \\
\text { permasalahan } \\
\text { sosial yang terjadi di masyarakat dengan cara } \\
\text { memahami kaitan pengelompokan sosial dengan }\end{array}$ & & \\
\hline & $\begin{array}{l}\text { 3.3 Memahami arti penting prinsip kesetaraan untuk } \\
\text { menyikapi } \\
\text { perbedaan sosial demi terwujudnya kehidupan }\end{array}$ & \multirow{2}{*}{\multicolumn{2}{|c|}{$\begin{array}{l}\text { - Kemampuan memecahkan } \\
\text { masalah } \\
\text { - Kerjasama/kolaborasi }\end{array}$}} \\
\hline & $\begin{array}{l}\text { 4.3 Menerapkan prinsip-prinsip kesetaraan untuk } \\
\text { mengatasi } \\
\text { perbedaan sosial dan mendorong terwujudnya }\end{array}$ & & \\
\hline & $\begin{array}{l}\text { 3.4 Menganalisis konflik sosial dan cara memberikan } \\
\text { respons } \\
\text { untuk melakukan resolusi konflik demi }\end{array}$ & \multirow[t]{2}{*}{$\mathrm{C} 4$} & \multirow{2}{*}{$\begin{array}{l}\text { - Berpikir kritis } \\
\text { - Berpikir kreatif } \\
\text { - Kerjasama/ } \\
\quad \text { kolaborasi }\end{array}$} \\
\hline & $\begin{array}{l}4.4 \text { Memetakan konflik untuk dapat melakukan } \\
\text { resolusi } \\
\text { konflik dan menumbuhkembangkan }\end{array}$ & & \\
\hline & $\begin{array}{l}\text { 3.5 Menganalisis cara melakukan pemecahan masalah } \\
\text { untuk mengatasi permasalahan sosial, } \\
\text { konflik dan kekerasan di masyarakat }\end{array}$ & \multirow[t]{2}{*}{$\mathrm{C} 4$} & \multirow{2}{*}{$\begin{array}{l}\text { - Kemampuan } \\
\text { memecahkan } \\
\text { masalah } \\
\text { - Berpikir } \\
\text { prosedural } \\
\text { - Kedisiplinan }\end{array}$} \\
\hline & $\begin{array}{l}\text { 4.5 Melakukan penelitian sederhana yang berorientasi } \\
\text { pada } \\
\text { pemecahan masalah berkaitan dengan permasalahan }\end{array}$ & & \\
\hline \multirow[t]{4}{*}{ XII } & $\begin{array}{l}\text { 3.2 Memahami berbagai permasalahan sosial yang } \\
\text { disebabkan }\end{array}$ & \multirow{2}{*}{\multicolumn{2}{|c|}{$\begin{array}{l}\text { - Kepedulian sosial } \\
\text { - Mandiri }\end{array}$}} \\
\hline & $\begin{array}{l}\text { 4.2 Mengategorisasi berbagai permasalahan sosial yang } \\
\text { disebabkan oleh globalisasi serta akibat-akibatnya } \\
\text { dalam kehidupan nyata di masyarakat sehingga } \\
\text { dapat merespon berbagai permasalahan sosial } \\
\text { dan ketimpangan yang disebabkan proses }\end{array}$ & & \\
\hline & $\begin{array}{l}\text { 3.3 Memahami faktor penyebab ketimpangan sosial dan } \\
\text { pertautannya dengan perubahan sosial di tengah- } \\
\text { tengah globalisasi }\end{array}$ & \multirow{2}{*}{\multicolumn{2}{|c|}{$\begin{array}{l}\text { - Kedermawanan } \\
\text { - Rasa ingin tahu } \\
\text { - Kerja keras }\end{array}$}} \\
\hline & $\begin{array}{l}\text { 4.3 Mengolah hasil kajian dan pengamatan tentang } \\
\text { ketimpangan sosial sebagai akibat dari perubahan } \\
\text { sosial di tengah-tengah globalisasi }\end{array}$ & & \\
\hline
\end{tabular}




\begin{tabular}{|c|c|c|c|}
\hline \multirow{2}{*}{ Kelas } & \multirow{2}{*}{ Kompetensi Dasar (KD) } & \multicolumn{2}{|r|}{ Materi } \\
\hline & & HOTS & Nilai Karakter \\
\hline & $\begin{array}{l}\text { 3.4 Mendeskripsikan pengetahuan bagaimana melakukan } \\
\text { strategi pemberdayaan komunitas dengan } \\
\text { mengedepankan nilai-nilai kearifan lokal di } \\
\text { tengah-tengah pengaruh } \\
\text { globalisasi }\end{array}$ & \multicolumn{2}{|c|}{$\begin{array}{l}\text { - Berpikir dan bertindak } \\
\text { kreatif }\end{array}$} \\
\hline XII & $\begin{array}{l}.5 \text { Mengevaluasi aksi pemberdayaan komunitas sebagai } \\
\text { bentuk kemandirian dlm menyikapi ketimpangan sosial }\end{array}$ & $\mathrm{C} 5$ & \multirow[b]{2}{*}{$\begin{array}{l}\text { - Berpikir dan bertindak } \\
\text { kreatif } \\
\text { - Kerja Keras }\end{array}$} \\
\hline & 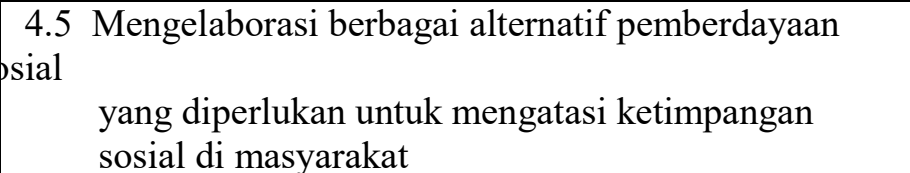 & & \\
\hline
\end{tabular}


Berdasarkan hasil identifikasi materi sosiologi di atas, karakter moral (moral character) seperti rasa hormat, keadilan, kebaikan, kejujuran secara eksplisit memang tidak muncul dalam Kompetensi Dasar (KD), namun dalam praktiknya nilai-nilai karakter tersebut muncul selama proses pembelajaran berlangsung. Substansi nilai sesungguhnya secara eksplisit atau implisit sudah ada dalam rumusan kompetensi (SKL, SK, dan KD) dalam Standar Isi Pendidikan Menengah. Yang perlu dilakukan lebih lanjut adalah memastikan bahwa pembelajaran materi pembelajaran tersebut memiliki dampak instruksional dan/atau dampak pengiring pembentukan karakter. Pengintegrasian nilai dapat dilakukan untuk satu atau lebih dari setiap pokok bahasan dari setiap materi pembelajaran. Seperti halnya sikap, suatu nilai tidaklah berdiri sendiri, tetapi berbentuk kelompok. Secara internal setiap nilai mengandung elemen pikiran, perasaan, dan perilaku moral yang secara psikologis saling berinteraksi. Karakter terbentuk dari internalisasi nilai yang bersifat konsisten, artinya terdapat keselarasan antarelemen nilai.

\section{Implementasi Rekayasa Praktek Pendidikan Karakter \& Pembelajaran HOTS}

Untuk mengimplementasikan hasil identifikasi Kompetensi Dasar (KD) mata pelajaran Sosiologi seperti pada Tabel 2 di atas, diperlukan strategi pembelajaran yang tepat dan rekayasa praktek pendidikan karakter. Berikut ini disajikan beberapa contoh bagaimana rekayasa praktek pendidikan karakter dapat digunakan sebagai strategi pembelajaran sosiologi berorientasi HOTS di kelas XII.

1. Kompetensi Dasar 4.2

Mengategorisasi berbagai permasalahan sosial yang disebabkan oleh globalisasi serta akibat-akibatnya dalam kehidupan nyata di masyarakat sehingga dapat merespon berbagai permasalahan sosial dan ketimpangan yang disebabkan proses globalisasi

a) Karakter Kinerja: Kepekaan Sosial, Mandiri

b) Rekayasa Praktek Pendidikan Karakter:

Guru menyajikan rubrik tugas yang memuat nilai-nilai pendidikan karakter kinerja sebagai berikut.

\section{Kepedulian Sosial}

Globalisasi merupakan perubahan sosial yang dapat berdampak positif dan negatif bagi masyarakat.

Dampak negatif globalisasi dapat 
berpengaruh bagi sebagian

masyarakat.

Oleh karena itu, dibutuhkan sikap

kepedulian sosial bagi setiap individu.

Bagaimana cara

mengamalkan sikap peduli sosial?

Coba terapkan kebiasaan berikut ini dalam kehidupan kalian.

1. Aktif dalam kegiatan sosial di lingkungan kalian

2. Membantu teman, keluarga, kerabat, atau orang lain yang memerlukan bantuan agar ketimpangan sosial dapat diminimalisir

3. Bersikap empati terhadap orang lain yang memiliki strata sosial di bawah kalian.

Dengan menerapkan kebiasaan tersebut, kalian telah menunjukkan sikap peduli sosial mulai dari lingkungan terdekat. Terapkan kebiasaan tersebut dalam kehidupan sosial kalian

\section{Mandiri}

Neokolonialisme merupakan dampak negatif dari globalisasi. Satu-satunya cara melepaskan diri dari jerat neokolonialisme adalah "berdikari" (berdiri di atas kaki sendiri). Ini sulit, tetapi tidak dapat ditawar. Kita tidak perlu antiasing, tetapi kita harus menjalin hubungan kemitraan yang sejajar dengan pihak asing tanpa mengorbankan kedaulatan. Agar mampu „berdikari“, diperlukan upaya-upaya peningkatan sumber daya manusia. Sumber daya manusia merupakan aset paling utama yang dimiliki suatu negara. Sumber daya manusia yang memiliki kualitas tinggi akan membebaskan negara dari jerat penindasan dan kemiskinan.

2. Kompetensi Dasar 4.3

Mengolah hasil kajian dan pengamatan tentang ketimpangan sosial sebagai akibat dari perubahan sosial di tengah-tengah globalisasi

a) Karakter Kinerja: Melatih kedermawanan, melatih rasa ingin tahu

b) Rekayasa Praktek Pendidikan

Karakter:

Guru memberi panduan observasi dan aksi sosial untuk melatih nilai-nilai pendidikan karakter kinerja sebagai berikut.

\section{Melatih Kedermawanan}

Ketimpangan sosial memang tidak secara cepat dapat langsung diatasi. Butuh proses panjang dan dukungan masyarakat untuk mengurangi kesenjangan sosial tersebut. Untuk melatih kedermawanan Kalian, lakukanlah aksi sosial melalui langkah-langkah sebagai berikut.

1. Sepakatilah bersama temanteman satu kelas bahwa akan dilaksanakan bakti sosial dengan mengumpulkan sebagian uang saku untuk membantu korban bencana

2. Pilihlah kejadian atau bencana yang terjadi dalam kurun waktu terdekat dan membutuhkan uluran tangan dari pihak lain. Mintalah bantuan guru jika menemui kesulitan

3. Bentuklah tim yang nantinya akan melaksanakan kegiatan. Mulailah dari lingkungan sekolah dengan memasuki setiap kelas dan meminta kesediaan teman Anda untuk berbagi seikhlasnya. Dana yang terkumpul, segera diberikan kepada penyalur bantuan atau minta bantuan guru

4. Jangan lupa membuat dokumentasi dan laporan singkat untuk dipajang pada mading sekolah sebagai tanda bukti pelaksanaan kegiatan

\section{Melatih Rasa Ingin Tahu}

"Indikasi siswa yang menerima Kartu Indonesia Pintar (KIP) 
adalah siswa miskin".

Lakukanlah observasi di lingkungan tempat tinggal Kalian untuk membuktikan pernyataan tersebut. Berdasarkan hasil observasi Kalian, adakah warga usia sekolah di lingkungan Kalian yang terdaftar dan menerima pembagian Kartu Indonesia Pintar? Berapa banyak siswa yang menerima jika dibandingkan siswa yang tidak menerima? Apa yang dapat Kalian simpulkan? Kemukakan pendapat Kalian secara lisan di depan kelas!

\section{c. Kompetensi Dasar 4.4}

Merancang, melaksanakan, dan melaporkan aksi pemberdayaan komunitas dengan mengedepankan nilai-nilai kearifan lokal ditengahtengah pengaruh globalisasi

1) Karakter Kinerja: berpikir dan bertindak kreatif, kemampuan memecahkan masalah

2) Rekayasa Praktek Pendidikan Karakter:
Guru memberi panduan
observasi dan aksi
sosial untuk melatih
nilai-nilai pendidikan
karakter kinerja sebagai
berikut.

\section{Berpikir dan Bertindak Kreatif}

Masyarakat Indonesia memiliki beragam bentuk kearifan lokal berkaitan dengan pemanfaatan air. Misalnya, sistem subak di Bali, sistem tudang sipulung di Sulawesi Selatan atau sistem tadah hujan. Kalian pun dapat melanjutkan usaha pelestarian kearifan lokal terkait pemanfaatan air dengan bertindak kreatif. Tindakan kreatif tersebut dapat dilakukan sebagai berikut:

1. Buatlah poster berkaitan dengan pemanfaatan air, misalnya tips, trik, ajakan, ataupun larangan agar menggunakan air secukupnya

2. Desainlah poster dengan kreasi yang menarik agar orang lain tertarik membaca dan mempraktikkannya

3. Pajanglah poster di tempat-tempat yang terdapat sumber air. Mintalah izin terlebih dahulu kepada pihakpihak yang berwenang

\section{Kemampuan Memecahkan Masalah}

Tujuan pemberdayaan adalah memberi daya dan memampukan kelompok masyarakat untuk memperbaiki kesejahteraan hidup. Proses pemberdayaan tidak selalu datang dari Pemerintah atau dari LSM (Lembaga Swadaya Masyarakat). Kalian pun dapat melaksanakan pemberdayaan masyarakat atau komunitas. Adapun prosedurnya sebagai berikut:

1. Bentuklah kelompok yang teridri atas 3-4 siswa

2. Observasilah terlebih dahulu masyarakat atau komunitas yang ingin Kalian berdayakan dan buatlah rancangan kegiatan yang cocok untuk dilaksanakan

3. Sesuaikan rancangan pemberdayaan dgn kemampuan, finansial, \& waktu yang Kalian miliki

4. Aspek-aspek yang perlu ada dalam rancangan pemberdayaan sebagai berikut:
a. Tujuan proses pemberdayaan
b. Kelompok/masyarakat yang menjadi fokus pemberdayaan
c. Deskripsi program pemberdayaan

5. Presentasikan rancangan program pemberdayaan yang Kalian buat agar mendapat masukan dari teman dan guru Kalian 
d. Kompetensi Dasar 3.5 dan 4.5

\subsection{Mengevaluasi aksi} pemberdayaan komunitas sebagai bentuk kemandirian dalam menyikapi ketimpangan sosial

\subsection{Mengelaborasi berbagai} alternatif pemberdayaan sosial yang diperlukan untuk mengatasi ketimpangan sosial di masyarakat

Karakter Kinerja: berpikir dan bertindak kreatif, kerja keras

$\underline{\text { Rekayasa Praktek Pendidikan }}$ Karakter:

Guru memberi rubrik

evaluasi pemberdayaan

masyarakat untuk melatih nilai- nilai pendidikan karakter kinerja sebagai berikut.

\section{Berpikir dan Bertindak Kreatif}

Seorang evaluator hendaknya melakukan kegiatan berikut sebelum melakukan kegiatan evaluasi pemberdayaan komunitas

1. Memikirkan secara matang dan membuat rancangan kegiatan yang perlu dilakukan saat melakukan evaluasi

2. Mencermati setiap proses kegiatan dan mencatat hal-hal penting saat pelaksanaan evaluasi

3. Mengambil tindakan sesuai prosedur dan rancangan kegiatan yang telah disusun

4. Fokus terhadap masalah dan berpikir kritis. Dengan demikian, evaluator mampu memberikan masukan dan hasil pengamatan secara obyektif

5. Mengatur emosi, sikap, \& perilaku saat kegiatan. Untuk itu perlu menggunakan bahasa yang baik \& mudah dimengerti agar maksud yang ingin disampaikan dapat diterima dengan baik

Dengan menerapkan upaya di atas, Kalian dapat mempersiapkan diri menjadi seorang evaluator pemberdayaan yang baik.

\section{Kerja Keras}

Evaluasi pemberdayaan komunitas tidak dapat berjalan baik apabila tidak dibarengi kerja keras. Kerja keras merupakan kunci meraih kesuksesan. Dengan melakukan kegiatan tersebut, Kalian dapat menunjukkan peran dalam komunitas di sekitar Kalian. Sebagai contoh, Kalian dapat berpartisipasi dalam kegiatan evaluasi pemberdayaan Karang Taruna dan organisasi di sekolah. Selanjutnya, Kalian dapat menyusun laporan kegiatan evaluasi sesuai hasil telaah dan menyampaikannya sebagai bahan masukan bagi Karang Taruna atau organisasi sekolah Kalian.

Agar rekayasa praktek pendidikan karakter dapat diterapkan dalam proses pembelajaran, dibutuhkan juga model $/$ metode pembelajaran yang tepat. Melalui model/metode pembelajaran, akan dapat diketahui pada sintaks atau tahapan mana rekayasa praktek pendidikan karakter itu mulai diterapkan. Apakah nilai-nilai karakter tersebut dapat diintegrasikan dalam rubrik tugas individu/kelompok, atau rubrik tersendiri yang memuat nilai-nilai karakter yang dirancang. Beberapa model/ metode pembelajaran yang sesuai dengan karakteristik mata pelajaran sosiologi misalnya, active learning, cooperative learning, contextual 
teaching and learning (CTL), inquiry leaning, problem-based learning, ataupun project-based learning.

Selama proses pembelajaran, peserta didik diberi kesempatan untuk berdiskusi tentang nilai-nilai karakter yang ingin dicapai baik secara individu ataupun kelompok. Selain itu ada juga tugas-tugas penulisan, observasi, dan pelaporan atas kegiatan yang telah dilaksanakan untuk merealisasikan nilainilai karakter yang telah dirancang oleh guru.

Kompetensi Dasar (KD) dan materi pelajaran yang berkaitan dengan norma atau nilai-nilai pada setiap mata pelajaran perlu dikembangkan, dieksplisitikan, dan dikaitkan dengan konteks kehidupan sehari-hari peserta didik. Dengan demikian, rekayasa praktik pendidikan karakter tidak hanya pada tataran kognitif, tetapi menyentuh pada internalisasi, dan pengalaman nyata dalam kehidupan peserta didik seharihari di masyarakat. Sementara itu, pembelajaran sosiologi berorientasi HOTS yang dirancang terlihat pada rubrik aktivitas siswa yang memuat aspek kognitif, seperti menganalisis dampak negatif globalisasi bagi masyarakat (C4), mengevaluasi program pemberdayaan yang ada di lingkungan tempat tinggal dan sekolah (C5), dan merancang program pemberdayaan komunitas di lingkungan tempat tinggal dan sekolah (C6).

Pada tahap implementasi ini dikembangkan pengalaman belajar (learning experiences) yang dibangun melalui rekayasa (intervensi) dan habituasi. Dalam rekayasa (intervensi) dikembangkan suasana interaksi pembelajaran yang dirancang untuk mencapai tujuan pembentukan karakter dengan penerapan pengalaman belajar terstruktur (structured learning experiences). Dalam habituasi diciptakan situasi dan kondisi yang memungkinkan peserta didik di mana saja membiasakan diri berperilaku sesuai nilai dan telah menjadi karakter dirinya, karena telah diinternalisasi dan dipersonifikasi melalui proses rekayasa (intervensi). Beberapa contoh di atas memerlukan upaya pengondisian sehingga peserta didik memiliki kesempatan untuk memunculkan perilaku yang menunjukkan nilai tersebut. Misalnya, untuk memiliki karakter kerja keras, peserta didik diminta melakukan observasi yang didahului dengan identifikasi masalah atau topik yang akan diinvestigasi lebih lanjut. Untuk dapat merealisasikan rencana yang telah disusun, peserta didik harus mengatur 
jadwal dengan detail dan memiliki semangat atau daya juang (kerja keras). Jika mereka tidak pandai mengatur jadwal dan tidak memiliki semangat atau daya juang (kerja keras), maka tugas yang diberikan oleh guru tidak akan bisa diselesaikan dengan tepat waktu dan sempurna.

\section{KESIMPULAN}

Rekayasa praktik pendidikan karakter pada prinsipnya tidak dimaksudkan untuk membuat kurikulum baru, tetapi terintegrasi ke dalam mata pelajaran. Dalam artikel ini, rekayasa praktik pendidikan karakter yang dimaksud adalah sebagai salah satu alternatif dalam strategi pengajaranpembelajaran sosiologi yang berorientasi HOTS. Mengapa demikian? Karena berdasarkan hasil identifikasi Kompetensi Dasar (KD) yang memuat keterampilan berpikir tingkat tinggi (HOTS) dalam Kurikulum 2013, terdapat nilai-nilai karakter kinerja (performance character) dan karakter moral (moral character). Nilai- nilai karakter ini selanjutnya dapat implementasikan dalam proses pembelajaran melalui suatu rekayasa (intervensi) yang dirancang oleh guru. Melalui cara ini maka pendidikan karakter yang dapat dikembangkan pada jenjang Sekolah Menengah Atas (SMA) tidak hanya selalu berkaitan/berfokus pada etika (karakter moral), namun juga memperhatikan keunggulan (karakter kinerja) yang muncul dalam kurikulum sosiologi SMA.

Dalam konteks ini setiap guru dapat memilih nilai-nilai pendidikan karakter yang sesuai dengan Kompetensi Dasar (KD), tema, atau pokok bahasan bidang studi; dan selanjutnya merancang rekayasa (intervensi) praktik pendidikan karakter. Melalui model terintegrasi mata pelajaran ini maka setiap guru adalah pengajar pendidikan karakter tanpa kecuali. Keunggulan model terintegrasi pada setiap bidang studi atau mata pelajaran antara lain setiap guru ikut bertanggung jawab akan penanaman nilai-nilai karakter (khususnya karakter kinerja) kepada semua siswa. Di samping itu, pemahaman akan nilai-nilai pendidikan karakter cenderung tidak bersifat informatif-kognitif, melainkan bersifat aplikatif sesuai dengan konteks pada setiap bidang studi atau mata pelajaran. Dampaknya siswa akan lebih terbiasa dengan nilai-nilai yang sudah diterapkan dalam berbagai setting sebagai pengalaman belajar terstruktur (structured learning experiences) yang dibangun melalui rekayasa (intervensi) dan habituasi. 
Sebagai catatan penutup, tantangan yang mungkin dihadapi guru dalam rekayasa praktik pendidikan karakter sebagai strategi pembelajaran sosiologi HOTS ini adalah adalah pemahaman dan persepsi tentang nilai yang akan ditanamkan harus jelas dan sama bagi semua guru. Namun, menjamin kesamaan bagi setiap guru adalah hal yang tidak mudah, hal ini mengingat latar belakang dan kompetensi setiap guru yang berbeda- beda. Di samping itu, mungkin juga akan terjadi perbedaan penafsiran nilai-nilai karakter diantara guru, khususnya berkaitan dengan Kompetensi Dasar (KD) yang akan dipelajari.

\section{DAFTAR PUSTAKA}

Anderson, L.W., dan Krathwohl, D.R. (2001). A Taxonomy for Learning, Teaching, and Assesing: $A$ Revision of Bloom "s Taxonomy of Educatioanl Objectives. New York: Addison Wesley Longman, Inc.

Bining, Arthur C. (1952). Teaching The Social Studies in Secondary Schools $\left(3^{\text {th }}\right.$ - New Delhi. ed.) Bombay

Burkhardt, H., \& Schoenield, A. H. (2003). Improving Educational Research: Toward a more Useful, Influential, and Better-funded Enterprise. Educational Researcher, 32(9),3-14.
Character Education Partnership (CEP). (2008). Performance Values: Why They Matter and what Schools can Do to Foster Their Development. Journal of Research in Character Education, 6(1), 73-81.

Davidson, M., Lickona, T., \& Khmelkov, V. (2015). Sekolah Pintar dan Baik: Paradigma Baru Pendidikan Karakter SMA. Dalam Handbook Pendidikan Moral dan Karakter (Penerj. Imam Baehaqie \& Derta Sri Widowatie). Judul Asli Handbook of Moral and Character Education (Eds. Larry P. Nucci \& Darcia Narvaez). Bandung: Nusa Media.

Dianti, P. (2014). Integrasi Pendidikan Karakter dalam Pembelajaran Pendidikan Kewarganegaraan untuk Mengembangkan Karakter Siswa. Jurnal Pendidikan Ilmu Sosial, 23(1), 58-68.

Duckworth, A., \& Seligman, M. (2005). Self-discipline outdoes IQ in predicting academic performance of adolescents. Psychological Science, 16, 939-944.

Ellis, Arthur K. (1997). Teaching and

Learning Elementary Social Studies.

Allyn and Bacon. Fogarty, R. (1991).

The Mindful School: How to Integrate the Curicula. Palatine,lllonois: IRI/Skylight Publishing. Inc.

Kemdiknas. (2010). Desain Induk Pembangunan Karater Bangsa. Jakarta: Kemendiknas.

Kristiawan, M., Ahmad, S., Tobari, \& Suhono. (2017). Desain Pembelajaran SMAPlus Negeri 2 Banyuasin III Berbasis Karakter di Era Masyarakat 
Ekonomi ASEAN. IDRA ${ }^{\text {ce }}$

(Jurnal Kajian Ilmu Pendidikan), 2(2), 403-432.

Kurniawan, S. (2013). Pendidikan Karakter: Konsepsi dan Implementasinya secara Terpadu di Lingkungan Keluarga, Sekolah, Perguruan Tinggi, dan Masyarakat. Yogyakarta: ArRuzz Media.

Leming, James. (2006). Curricular Effectiveness in Moral Values Education: A Riview of Research. Journal of Moral Education. University at Carbondale, Southern Illinois

Leming, J.S. (2015). Penelitian dan Praktek dalam Pendidikan Moral dan Karakter: Dua Fenomena yang Berjauhan. Dalam Handbook Pendidikan Moral dan Karakter (Penerj. Imam Baehaqie \& Derta Sri Widowatie). Judul Asli Handbook of Moral and Character Education (Eds. Larry P. Nucci \& Darcia Narvaez). Bandung: Nusa Media.

Lickona, T. (2004). Character matters: How to help our children develop good judgment, integrity, and other essential virtues. New York: Simon \& Schuster.

Lickona, T., \& Davidson, M. (2005). Smart and good high schools: Integrating excellence and ethics for success in school, work, and beyond. Cortland, NY: Center for the 4th and 5th Rs (Respect and Responsibility).Washington,

D.C.: Character Education Partnership.

Mills, C. Wright. (1959). The

Sociological Imagination. New York: Oxford University

Press.
Sadia, I, W., Arnyana, I.B.P., \&

Muderawan, I.W. (2013). Model

Pendidikan Karakter

Terintegrasi Pembelajaran Sains.

Jurnal Pendidikan Indonesia, 2(2), 209-220.

Schwartz, M. J., Beatty, A., \& Dachnowicz, E. (2006). Character education: Frill or foundation? Principal Leadership, 7 (4-21).

Seider, S., Novick, S., \& Gomez, J. (2013). The Effects of Privileging Moral or Performance

Character Development in Urban Adolescents. Journal of Early Adolescence, 33(6), 786-820.

Shaver, J. P. (2001). The future of research on social studies - For what purpose? In W. B.

Stanley (Ed.), Current issues in social studies research for the 21st century (pp. 231-

252). Greenwich, CT: Information Age Publishing.

Strike, K.A. (2015). Sekolah, Komunitas, dan Pendidikan Moral. Dalam Handbook Pendidikan Moral dan Karakter (Penerj. Imam Baehaqie \& Derta Sri Widowatie). Judul Asli Handbook of Moral and Character Education (Eds. Larry P. Nucci \& Darcia Narvaez). Bandung: Nusa Media.

Suyadi. (2015). Strategi Pembelajaran Pendidikan Karakter. Bandung: Remaja Rosdakarya. Vincenti, W. G. (1990). What Engineers Know and How They Know It: Analytical Studies From Aeronautical History. Baltimore, 
MD: The John Hopkins

University Press.

Winataputra, Udin Saripudin. (1989).

Konsep dan Masalah Pengajaran Ilmu

Sosial di

Sekolah Menengah. Jakarta:

Depdikbud

Yanti, N., Adawiah, R., \& Matnuh, H. (2016). Pelaksanaan Kegiatan Ekstrakurikuler dalam Rangka

Pengembangan Nilai-nilai

Karakter Siswa untuk Menjadi

Warga Negara yang Baik di SMA KORPRI Banjarmasin. Jurnal Pendidikan

Kewarganegaraan, 6(11), 963-970.

Zubaedi. (2011). Desain Pendidikan Karakter: Konsepsi dan Aplikasinya dalam Lembaga

Pendidikan. Jakarta: Kencana.

Zuriah, N., Widodo, R., \& Sunaryo, H. (2016). Model Pendidikan Karakter Berbasis Nilai Kearifan Lokal dan Civic Virtue Sebuah Rekayasa Sosial. Makalah. Disampaikan dalam Seminar Nasional dan Gelar Produk (SenasPro) Universitas Muhammadiyah Malang tanggal 17-18 Oktober 2016. Tersedia di: http://researchreport.umm.ac.id/index.php/researc h-report/article/viewFile/771/9 